\title{
SYSTEM OF TECHNICAL REGULATION AND CONFORMITY ASSESSMENT OF UKRAINE AND CHINA. COMPARATIVE ANALYSIS OF LEGISLATION ON PRODUCT QUALITY AND SAFETY
}

\author{
N. KONDRATJUK, PhD, Associate Professor \\ (Oles Honchar Dnipro National University); \\ T. STEPANOVA, PhD, Associate Professor \\ (Sumy National Agrarian University); \\ O. KOZHEMIAKA; \\ K. SUPRUNENKO \\ (Oles Honchar Dnipro National University)
}

\begin{abstract}
The article presents the results of monitoring the situation regarding technical regulation and regulatory requirements in Ukraine and China. The essence of asymmetries that are present in the legislative, technical and practical areas of activity in matters of product quality is explained. The analysis of discrepancies between normative requirements of quality and safety of industrial and food production is given. The main obstacles to the free transfer of goods and services between the two countries are indicated. The evolution of the formation of the system of technical regulation in China and the measures that ensured the reform of the system of technical regulation in Ukraine are traced. The results of this monitoring will harmonize the processes of economic policy implementation in the direction of integrating Ukrainian goods into Chinese markets. The main conclusion of the article is the proposals to remove technical barriers to trade between Ukraine and China. This will regulate the harmonization of technical regulation systems in both countries, as well as modernize and increase the competitiveness of the state economy as a whole.
\end{abstract}

Keywords: technical regulation system, economic competitiveness, standardization, international economic integration, China, Ukraine.

Formulation of the problem in a general form and connection with the most important scientific or practical tasks. An effective system of technical regulation is a factor in the transition and successful adaptation of the country in the world economic space. In addition, the levers of the system can increase the competitiveness of products. This becomes an impetus for the economic development of the country and expands labor in the direction of innovation. The diffusion of innovations into the economic space allows to overcome obstacles in entering world markets, especially in high-tech areas.

Paying attention to the issue of competitiveness of domestic goods and markets in the era of economic globalization for countries that have scientific, creative and technical potential should be an imperative for growth. It is important to take into account the high level of interdependence of countries [1]. The processes of globalization are subject to the laws of trade liberalization and capital movements, deregulation and technology development. They are made against the background of political decisions with full national and world autonomy. It is necessary to understand that it is very important to occupy new markets and niches without the levers of cooperation: international agreements, regional integration and support of international organizations.

The division of international labor becomes effective when all players follow trade and monetary policies, as well as competition rules. In this regard, Ukraine's integration into the world economy is of interest not only in the European direction, but also in the Asian direction. Our country is seen as a powerful strategic partner from the East, 
especially for China. Therefore, the harmonization of the technical regulation system between the two countries, especially on quality issues, is relevant and requires the attention of experts.

Analysis of recent research and publications. This article provides an overview of current trends in international food quality standards for China and Ukraine. It also presents recommendations for the harmonization of the technical regulation system, based on the social needs that determine this point of view. According to preliminary monitoring of the situation based on existing information in the literature, the differences between world rules, regulations adopted to the leadership in China and the domestic approach to technical regulation are recognized. These differences create a gap in addressing the main issues of food quality. In particular, this applies to nutritional value and control of nutrients, daily intake of nutrients and their level of consumption. This is a determining factor in harmonization and gives globality to the issues discussed in this article [2].

Works by Ukrainian and foreign authors: A. Khanet, J. Belisl, M. Lemel, L. Bal-Prilipko, O. Belous, I. Burakovsky, L. Vitkin, P. Kalita, O. Kalmykova, M. Kohut, Yu. Kozhedub, N. Lebid is devoted to the problems of creating and ensuring the proper functioning of the system of technical regulation, overcoming obstacles in ensuring effective foreign economic activity, development of principles of harmonization of the system of technical regulation. Likewise the main problems of synchronization and harmonization are covered in the works [2] and [3]. Noting the contribution of scientists to the development of research on these issues, it should be noted that little attention is paid to the place of technical regulation in the export policy of the state in general and the competitiveness of the Ukrainian economy in particular.

The system of technical regulation is most comprehensively considered in textbooks, manuals, guidelines [4]. The authors point to the scientific, regulatory, technical and organizational foundations for standardization, metrological support, quality management, certification and accreditation. However, considering the components of technical regulation, it is necessary not only to understand the system as a whole, but also as a system that moves to achieve the end result.

Information about Ukrainian international cooperation in the field of metrology, standardization and certification is widely covered in the
Ukrainian scientific literature. [4]. Most authors consider purely technical aspects of technical regulation and focus on scientific and technical principles and methods of standardization $[5,6]$.

It should be noted that the lack of harmonization of technical regulation systems between Ukraine and China makes it impossible to introduce innovative technologies.

Formulation of the objectives of the article. The main purpose of the article is to assess the compliance of technical regulation systems in Ukraine and China as a basis for overcoming technical barriers to the transfer of goods and services and to increase the competitiveness of domestic producers.

The technical regulation system has several components. Standardization system of Ukraine needs to be considered in terms of increasing innovation and reducing the gap with world market leaders. The following tasks were set to solve in the context of achieving the goal:

- to determine the category of "technical regulation system" and ways of its implementation in Ukraine;

- to conduct a comparative analysis of the national system of technical regulation and the corresponding system in China;

- to develop proposals for the removal of technical barriers in the system of technical regulation of both countries in terms of providing opportunities for innovation.

Presentation of the main research material with full justification of the obtained scientific results. The national system of technical regulation of Ukraine was developed in accordance with the Concept of state systems of standardization, metrology and certification, adopted by the Cabinet of Ministers in May 1992.

Ukraine became a member of the International Organization for Standardization (ISO) and the International Electrotechnical Commission (IEC), a corresponding member of the International Organization of Legal Metrology (OIML), the European Committee for Standardization (CEN) and the European Committee for Electrotechnical Standardization (CENELEC). Ukraine has become a full member of the Metric Convention since 2018. Ukraine has joined the Code of Voluntary Practice for the Preparation, Adoption and Implementation of Standards under the Agreement on Technical Barriers to Trade of the World Trade Organization (WTO).

Ukraine joined the WTO in 2008, in 2014 signed an Association Agreement between Ukraine and 
the European Union. The national technical regulation system is currently undergoing modernization. Since $1^{\text {st }}$ of January, 2016 European standards are gradually being introduced on the territory of Ukraine instead of national ones.

As it is known, the People's Republic of China became a member of the WTO in December 2001. After joining the WTO, China not only assumed the obligations stipulated by the WTO Agreement on Technical Barriers to Trade, but also actively uses the provisions of this document, including pursuing a protectionist policy to protect interests of national producers.

The Standardization Administration of China (SAC) represents China for participation in the International Organization for Standardization (ISO), the International Electrotechnical Commission (IEC), the PASC (Pacific Area Standards Congress) and other international or regional standardization organizations.

Table 1 provides a comparative analysis of the main basic acts of legislation in the field of technical regulation for Ukraine and China [7, 8].

Table 1

\section{The main basic acts of legislation in the field of technical regulation}

\begin{tabular}{|c|c|}
\hline Ukraine & China \\
\hline $\begin{array}{l}\text { The Law of Ukraine on Metrology and Metrological } \\
\text { Activity }\end{array}$ & The Law on Metrology of the People's Republic of China \\
\hline $\begin{array}{l}\text { The Law of Ukraine on Technical Regulations and } \\
\text { Conformity Assessment }\end{array}$ & Product Quality Law of The People's Republic of China \\
\hline The Law of Ukraine on Standardization & The Law on Standardization of the People's Republic of China \\
\hline $\begin{array}{l}\text { The Law of Ukraine on Accreditation of Conformity } \\
\text { Assessment Bodies }\end{array}$ & \\
\hline $\begin{array}{l}\text { The Law of Ukraine on State Market Supervision and } \\
\text { Control of Non-Food Products }\end{array}$ & \\
\hline $\begin{array}{l}\text { Law of Ukraine on the General Safety of Non-food } \\
\text { Products }\end{array}$ & \\
\hline
\end{tabular}

As can be seen from Table 1, Ukraine has a wider range of basic legislative acts than China. In this regard, it became necessary to analyze the spheres of technical regulation.

The modern sphere of technical regulation of Ukraine operates with the following types of regulatory documents:

A technical regulation is a normative legal act approved by the Verkhovna Rada of Ukraine, the Cabinet of Ministers of Ukraine, general or individual decisions of European legislative bodies - the European Commission, the European Council, the European Parliament. It defines the characteristics of the product or associated processes or production methods, and the requirements for services.

Technical regulations are part of the national regulatory framework. These standards are binding. They relate to equipment, machinery and mechanisms.

A standard is a consensus document approved by a notified body. It establishes rules, instructions or characteristics concerning an activity or its results, products, processes or services. A standard may contain requirements for terminology, designations, packaging, labeling that apply to a specific product or service, process or production method.

The standards are applied on a voluntary basis and are not binding.

However, one must correctly understand the principle of voluntary use. The market operator can choose any of the available standards or develop their own and further adhere to the requirements of the selected regulatory document. In addition, according to the Law on Standardization, compliance with standards is a voluntary procedure, except for manufacturers of 9 types of products. These are construction products, oil products, firearms, self-defense equipment, security systems, fire-fighting products, radiation equipment, electric vehicles and tobacco products.

A specification is a document approved by the manufacturer or other market operator. It defines the technical requirements for products and their manufacturing processes.

In the National Standards System of China, standards of the following categories are designated:

National standards. They are divided into mandatory, i.e. technical regulations and voluntary;

Industry standards;

Regional standards; 
Corporate standards.

A significant part of the standards of Ukraine and China are harmonized with international standards.

There are the following forms of conformity assessment in Ukraine:

1. Certification of products and the use of marks of conformity;

2. Test results obtained in accredited laboratories;

3. Declaration of conformity issued by the manufacturer, which can be combined with the use of a surveillance system.

There are the following main forms of confor- mity assessment in PRC:

1. Mandatory certification;

2. Inspection;

3. Registration of certain groups of goods (for example, medical equipment and medical products, fertilizers, pesticides, medicines, dietary supplements).

Gradually, radical institutional transformations are being carried out aimed at improving interdepartmental coordination and eliminating duplication of regulatory functions both in Ukraine and in China.

Food safety regulatory authorities in both countries are summarized in Table 2.

Table 2

\section{Regulatory bodies in the food safety system}

\begin{tabular}{|l|l|}
\hline \multicolumn{1}{|c|}{ Ukraine } & \multicolumn{1}{|c|}{ People's Republic of China } \\
\hline Ministry of Economic Development and Trade of Ukraine & $\begin{array}{l}\text { Ministry of Agriculture and Rural Affairs of the } \\
\text { People's Republic of China }\end{array}$ \\
\hline State Service of Ukraine for Food Safety and Consumer Protection & State Administration for Market Regulation (SAMR) \\
\hline Ministry of Health of Ukraine & National Health Commission of the PRC (NHC) \\
\hline Ministry of Ecology and Natural Resources of Ukraine & Ministry of Commerce of the PRC \\
\hline $\begin{array}{l}\text { Subcommittee on the Management of Sanitary and Phytosanitary } \\
\text { Measures of the Trade Association Committee }\end{array}$ & Ministry of Public Security of the PRC \\
\hline & $\begin{array}{l}\text { Certification and Accreditation Administration of the } \\
\text { PRC (CNCA) - functions are combined with SAMR }\end{array}$ \\
\cline { 2 - 2 } & $\begin{array}{l}\text { Standardization Administration of China (SAC) - } \\
\text { functions are combined with SAMR }\end{array}$ \\
\hline
\end{tabular}

In accordance with the plan for the implementation of the Association Agreement between Ukraine and the European Union, Ukraine has adopted a number of legislative acts. They lay the foundation for reforming the food safety assur- ance system by implementing the main European principles and practices.

A comparative analysis of the legislative framework of Ukraine and China in the field of food safety is presented in the Table 3 .

\section{Legislative framework in the field of food safety}

\begin{tabular}{|l|l|}
\hline \multicolumn{1}{|c|}{ Ukraine } & \multicolumn{1}{|c|}{ People's Republic of China } \\
\hline $\begin{array}{l}\text { The Law of Ukraine on Basic Principles and Requirements for } \\
\text { Food Safety and Quality }\end{array}$ & Law on Food Safety \\
\hline The Law of Ukraine on Food Information for Consumers & Law on Quality and Safety of Agricultural Products \\
\hline The Law of Ukraine on Feed Safety and Hygiene & Law on Food Hygiene \\
\hline $\begin{array}{l}\text { Draft Law on Requirements for Items and Materials in Contact } \\
\text { with Food }\end{array}$ & Law on Consumer Protection \\
\hline $\begin{array}{l}\text { The Law of Ukraine on Basic Principles and Requirements for } \\
\text { Organic Production, Treatment and Labeling of Organic Products }\end{array}$ & Law on Inspection of Import and Export Products \\
\hline The Law of Ukraine on Animal Identification and Registration & $\begin{array}{l}\text { Law on Quarantine in the Import and Export of } \\
\text { Animals and Plants }\end{array}$ \\
\hline $\begin{array}{l}\text { The Law of Ukraine on State Control over Observance of } \\
\text { Legislation on Foodstuffs, Feeds, Animal By-Products, Animal } \\
\text { Health and Welfare }\end{array}$ & $\begin{array}{l}\text { Special Rules of the State Council of the People's } \\
\text { Republic of China on Strengthening Supervision and } \\
\text { Administration of Food and Other Product Safety }\end{array}$ \\
\hline The Law of Ukraine on Seeds and Planting Material & Law on domestic grain production \\
\hline
\end{tabular}


A draft Law of Ukraine "On Amendments to Certain Laws of Ukraine Concerning Tracking and Labeling of GMOs in Food, Feed, Veterinary Products" has been developed.

On November 27, 2020, the Ministry of Economic Development, Trade and Agriculture of Ukraine published the draft Law of Ukraine "On Amendments to Certain Laws of Ukraine Concerning Food Products and Other Objects of Sanitary Measures".

The draft Law strengthens state control and responsibility for violation of legislation in the field of food safety and quality, including falsification of food products. Also, the provisions of the current legislation on the issues of state registration of food additives, enzymes and flavorings in Ukraine are being brought into compliance. The concept of "craft production" and the like is also introduced.

On September 20, 2019, Section VII of the Law of Ukraine "On basic principles and requirements for safety and quality of food" came into force. This completed the third phase of the transition of enterprises to the new HACCP food safety control system.

HACCP (Hazard Analysis and Critical Control Point) is a scientifically based system that allows to identify, assess and control hazards that are significant for food safety. HACCP is a hazard assessment tool and a control system that focuses on preventive measures rather than testing the end product.

The goal of implementing the HACCP system is the production of safe food products. Three controlled stages are created for this: hazard prevention, hazard prevention and hazard elimination.

Food market operators are responsible for developing and implementing practices (HACCP) that help prevent, minimize or eliminate risks that affect food safety.

Governments are responsible for monitoring and verifying the effectiveness of risk management measures. In Ukraine, the competent authority responsible for monitoring and verification is the State Service of Ukraine for Food Safety and Consumer Protection.

The China National Center for Food Safety Risk Assessment (CFSA) operates within the PRC National Health Commission (NHC). The CFSA is a technical institution that assesses food safety risks and provides technical support in managing those risks and developing and revising related standards.

The government standards in China (Guobiao or GB) are the most influential group of standards from a legal point of view. State food safety stan- dards have a wide scope, are mandatory for all manufacturers, processors, sellers, exporters, importers of food products, food additives and related products and, among other things, set limits on the content of heavy metals, pollutants and other harmful to health. substances. Nowadays, the formation of the legislative framework in the field of food safety is actively continuing.

Certain difficulties in conducting a comparative analysis arose due to the lack of publicly available Chinese state standards in this area.

Conclusions from these problems and prospects for further research in this area. Food companies interested in expanding their export destinations need to understand the quality and safety requirements of their target markets.

Therefore, Ukrainian exporters are encouraged to conduct substantive consultations with Chinese partners/importers and regulatory authorities on each individual item. This is especially true of goods, the import of which to the PRC is just beginning.

An option to eliminate technical barriers to trade is to harmonize the system of technical regulation in Ukraine with EU requirements. This is relevant and urgent not only from the standpoint of removing barriers, but also technical modernization, increasing the competitiveness of the economy as a whole.

\section{СПИСОК ВИКОРИСТАНИХ ДЖЕРЕЛ}

1. Лукьяненко Д. Г. Глобальное экономическое развитие: тенденции, асимметрии, регулирование : монография / Д. Г. Лукьяненко, А. М. Поручник, В. Н. Колесов. - Київ : ГВУЗ «Киевский национальный экономический университет имени Вадима Гетьмана», 2013. - 465 c.

2. Vintila I. Current legislations in nutrition and issues requiring global harmonisation / I. Vintila, V. Y. Waisundara, H. L. M. Lelieveld // Quality Assurance and Safety of Crops \& Foods. - 2019. - № 11(7). - P. 593-601.

3. International Harmonization of Food and Nutrition Regulation: The Good and the Bad / B. P. Fitzgerald, K. R. France // Journal of Public Policy \& Marketing. - 2003. № 1(22). - P. 102-110. 
4. Нагорна О. О. Система технічного регулювання як складова інноваційного розвитку економіки України / О. О. Нагорна // Ефективна економіка. - 2014. - № 6. - С. 63-69.

5. Димань Т. М. Безпека продовольчої сировини і харчових продуктів: підручник / Т. М. Димань, Т. Г. Мазур. - Київ : ВЦ «Академія», 2011. - 520 с.

6. Штефан Н. В. Технічне регулювання в Україні: проблеми та досягнення / Н. В. Штефан // Системи обробки інформаціiі. - 2011. - № 6(96). - С. 17-19.

7. Про метрологію та метрологічну діяльність [Електронний ресурс] : Закон України. - Режим доступу: https://zakon2.rada. gov.ua/laws/show/124-19 (дата звернення: 15.10.2020). - Назва $з$ екрана.

8. Про стандартизацію [Електронний ресурс] : Закон України від 05.06.2014 № 1315_VII. - Голос України. 2014. № 124. - Режим доступу: http://zakon.rada. gov.ua/laws/show/1315_18 (дата звернення: 15.10.2020). - Назва з екрана.

\section{REFERENCES}

1. Luk'janenko D. G. (2013). Globalnoe ekonomicheskoe razvitie: tendencii, asimmetrii, regulirovanie [Global economic development: trends, asymmetries, regulation]. Kyiv, GVUZ. [in Russian].

2. Vintila I., Waisundara V. Y. \& Lelieveld H. L. M. (2019). Current legislations in nutrition and issues requiring global harmoni- sation, Quality Assurance and Safety of Crops \& Foods., 11 (7), 593-601. [in English].

3. Fitzgerald B. P. \& France K. R. (2003) International Harmonization of Food and Nutrition Regulation: The Good and the Bad. Journal of Public Policy \& Marketing, 1(22), 102-110. [in English].

4. Nahorna O. O. (2014) Systema tehnichnogo reguljuvannja jak skladova innovacijnogo rozvytku ekonomiky Ukrai'ny [The system of technical regulation as a component of innovative development of the economy of Ukraine]. Efektyvna ekonomika - Efficient economy, 6, 63-69 [in Ukrainian].

5. Dyma T. M. (2011). Bezpeka prodovolchoi syrovyny $i$ harchovyh produktiv [Safety of food raw materials and food products]. Kyiv, VC "Akademija" [in Ukrainian].

6. Shtefan N. V. (2011). Tehnichne reguljuvannja v Ukraini: problemy ta dosjagnennja [Technical regulation in Ukraine: problems and achievements]. Systemy obrobky informacii Information processing systems, 6(96), 17-19 [in Ukranian].

7. Pro metrolohiyu ta metrolohichnu diyalnist : Zakon Ukrayiny [Law of Ukraine "On Metrology and Metrological Activity"]. Available at: https://zakon2.rada.gov.ua/laws/show/124-19 8 (accessed 15 October 2020) [in Ukranian].

8. Pro standartyzatsiyu: Zakon Ukrayiny [Law of Ukraine "On Standardization"]. Available at: http://zakon.rada.gov.ua/ laws/show/1315_18 (accessed 15 October 2020) [in Ukranian].

Н. В. Кондратюк, кандидат технічних наук, доцент (Дніпровський національний універcumem імені Олеся Гончара); Т. М. Степанова, кандидат технічних наук, доцент (Сумський національний аграрний університет); О. В. Кожемяка; К. Є. Супруненко (Дніпровський національний університет імені Олеся Гончара). Система технічного регулювання та оцінка відповідності України та КНР. Порівняльний аналіз законодавства щодо якості та безпеки продукції.

Анотація. У статті надається опис ефрективно діючої системи технічного регулювання як чинника переходу й успішної адаптації країни у світовому економічному просторі. Також матеріали статті містять інфрормацію про важелі системи, що дозволяють підвищити конкурентоспроможність продукції для економічного розвитку країни та поширення трудової діяльності в напрямі інновацій. У статті наведено результати моніторингу ситуації щодо 
технічного регулювання та нормативних вимог в Україні та Китаї. Роз'яснено сутність асиметрій, що присутні в законодавчій, технічній та практичній сфрерах діяльності в питаннях якості продукції. Приведено аналіз невідповідностей між нормативними вимогами забезпечення якості та безпечності промислової і продовольчої продукції. Вказано основні перешкоди для здійснення вільного трансферу товарів і послуг між двома країнами. Простежено еволюцію формування системи технічного регулювання в КНР і заходи, що забезпечили рефрормування системи технічного регулювання в Україні. Результати приведеного моніторингу дозволять гармонізувати процеси реалізації економічної політики в напрямі інтегрування українських товарів на ринки КНР. Основним висновком матеріалів статті $\epsilon$ пропозиції щодо усунення технічних бар'єрів у торгівлі між Україною та Китаєм, що дозволять врегулювати питання гармонізації систем технічного регулювання в обох країнах, а також модернізувати та підвищити конкурентоспроможність державної економіки в цілому. А саме: підприємства харчового сектора, зацікавлені в розширенні своїх напрямів експорту, повинні розуміти вимоги до якості та безпеки своїх цільових ринків, тому українським експортерам рекомендується проводити предметні консультації з китайськими партнерами/імпортерами та контролюючими державними органами з кожної окремої позиції, особливо щодо товарів, імпорт яких у КНР тільки починається.

Ключові слова: система технічного регулювання, конкурентоспроможність економіки, стандартизація, міжнародна економічна інтеграція, Китай, Україна.

H. В. Кондратюк, кандидат технических наук, доцент (Днепровский национальный университет имени Олеся Гончара); Т. М. Степанова, кандидат технических наук, доцент (Сумской национальный аграрный университет); О. В. Кожемяка; Е. Е. Супруненко (Днепровский национальный университет имени Олеся Гончара). Система технического регулирования и оценка соответствия Украины и КНР. Сравнительный анализ законодательства по качеству и безопасности продукции.

Аннотация. В статье приведены результаты мониторинга ситуации в сфрере технического регулирования и нормативных требований в Украине и Китае. Разъяснена сущность асимметрий, которые присутствуют в законодательной, технической и практической сфрерах деятельности в вопросах качества продукции. Приведен анализ несоответствий между нормативными требованиями качества и безопасности промышленной и продовольственной продукции. Указаны основные препятствия для осуществления свободного трансфрера товаров и услуг между двумя странами. Прослежена эволюция фрормирования системы технического регулирования в КНР и меры, которые обеспечили рефрормирование системы технического регулирования в Украине. Результаты приведенного мониторинга позволят гармонизировать процессы реализации экономической политики по направлению интеграции украинских товаров на рынки КНР. Основным выводом материалов статьи есть предложения по устранению технических барьеров в торговле между Украиной и Китаем, которые позволят урегулировать вопрос гармонизации систем технического регулирования в обеих странах, а также модернизировать и повысить конкурентоспособность государственной экономики в целом.

Ключевые слова: система технического регулирования, конкурентоспособность экономики, стандартизация, международная экономическая интеграция, Китай, Украина. 